\title{
Arab(ic) Emotions - Back to the Roots!
}

\section{Stephan Guth (IKOS, University of Oslo)}

This contribution is inspired by two projects that have been dear to the eminent researcher who is being honoured by the present festschrift: Travelling Emotions and the Bibliotheca Polyglotta. The first is, as we are told on the project's homepage, "an inter-departmental research network at the Arts Faculty (HF) [of the University of Oslo, Norway]", initiated by Jens Braarvig, aiming at "the study of emotions in language and the way they (their words, concepts and forms of expression) have changed - travelled - in time, place, as well as in society and text." "Dealing myself with such a kind of "travelling" in my research on Arabic etymology and semantic history, where words and concepts often are borrowed into Arabic from outside or can be followed on their way from Arabic into other languages, I thought it might be a nice idea to contribute to the festschrift with a study on the etymology of some Arabic "emotional" terminology. All the more so since Jens Braarvig was so kind to host my own "zero-version" of an Etymological Dictionary of Arabic on "his" Bibliotheca Polyglotta platform. ${ }^{2}$ In search of a manageable selection of terms I came across a taxonymy of emotions suggested by the late Robert Plutchik (1927-2006), a former professor emeritus at the Albert Einstein College of Medicine and adjunct professor at the University of South Florida. ${ }^{3}$ Plutchik is particularly known for his visualization, in form of a wheel, of the relations between thirty-two key emotions - now mostly called "Plutchik's Wheel of Emotions":

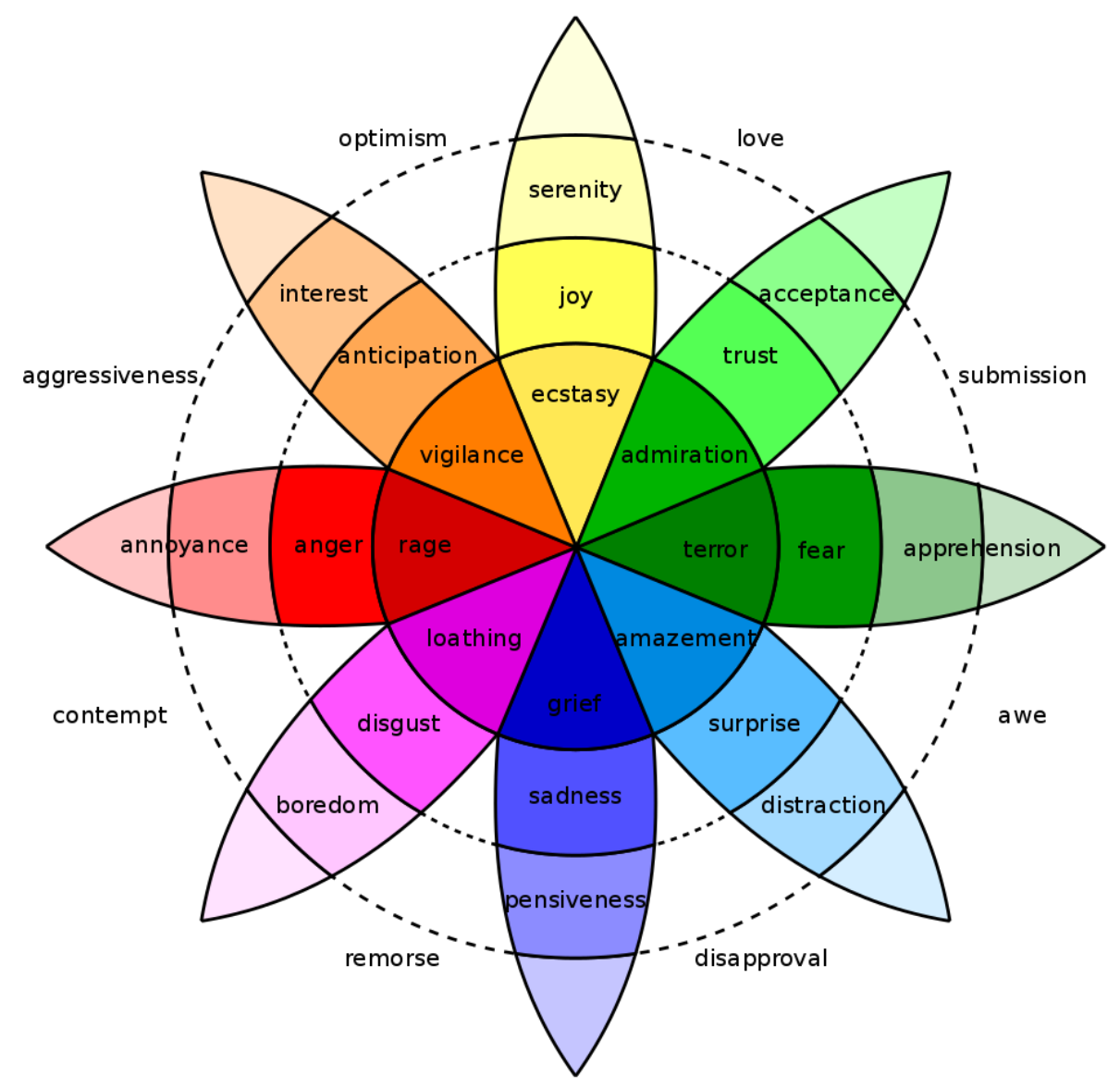

\footnotetext{
<http://www.hf.uio.no/iln/forskning/nettverk/digital-humaniora/travelling-emotions.html $>$.

$<$ https://www2.hf.uio.no/polyglotta/>.

$<$ https://en.wikipedia.org/wiki/Robert_Plutchik> (as of August 16, 2017).

$<$ https://en.wikipedia.org/wiki/File:Plutchik-wheel.svg> (as of August 16, 2017).
} 
There is an Arabic translation of his terminology in a corresponding entry in the Arabic Wikipedia, ${ }^{5}$ i.e., an example of a text that had travelled from one language and culture to another, so that I only had to pick out a set of emotions that seemed both appealing and manageable in the limits of a festschrift article. I ended up with the eight terms of the circle that was closest to the central one and contained what in English was labelled the eight "basic emotions": joy and sadness, trust and disgust, fear and anger, and surprise and anticipation, and what the entry presented as their modern Arabic equivalents,

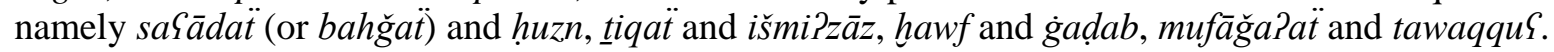

In the following article, I will try to go back to the roots, i.e., search for the possible origins of these Arabic terms. As we shall see, this is more problematic than expected, although, supposedly, we are dealing with "basic" emotions...

\section{Joy—sạädä̈}

$\sqrt{ } \mathbf{S C D}$

There are two Arabic words with which Plutchik's joy is equated in the above-mentioned article. In the figure showing Plutchik's "wheel of emotions," the equivalent given is bah ̌a $\ddot{t}$ while in the corresponding table the latter's place is taken by saqädä̈. ${ }^{6}$ According to Wehr/Cowan's Dictionary, the meaning of saৎādä̈ in MSA is not really 'joy' but rather 'happiness'. Bahğä̈ does render 'joy, delight', but it is also 'splendor, magnificence, beauty, resplendence'. In my own opinion, 'joy' should rather be translated by surür, marah, or gibtä̈ (which is what one gets by looking up the German equivalent of English 'joy', 'Freude,' in Schregle's Deutsch-Arabisches Wörterbuch), or farah (given by Osman in his follow-up dictionary of Schregle's, in addition to bahğä̈). The variety of possible renderings demonstrates that English 'joy' (German 'Freude') obviously does not have one clear and unambiguous equivalent in Arabic; there are several terms that may express specific aspects of this emotion. Given limitation of space, I will only focus on one here. The most interesting, from the etymological point of view, is certainly sa؟ $\bar{a} d a \ddot{t}$ because the root $\sqrt{S} S \mathrm{D}$ to which it belongs displays the most varied semantic spectrum. In MSA, the values attached to this root are (as manifest in some main representatives):

\#1 saSd 'good luck, good fortune', saSāalä 'happiness; bliss, felicity; good fortune, success, prosperity, welfare; bliss, felicity', sa५id 'happy (bi- about, at); radiant, blissful; lucky, auspicious; felicitous'

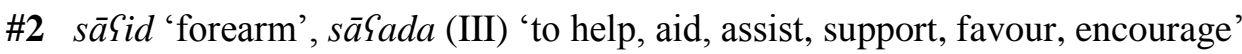

\#3 suSd 'nipple, teat'

\#4 sasdān 'ape, monkey'

\#5 sądānä̈ 'Cyperus (bot.)

According to Badawi \& Abdel Haleem 2008, the first two are also the main values in Classical Arabic: ' $\mathbf{1}$ happiness, fortune; $\mathbf{2 a}$ assistance; $\mathbf{2 b}$ arm, power'. But there are, of course, more. Here is what one finds in the concise dictionaries of Hava 1899 and Steingass $1884^{7}$ (to manageably treat the information contained in the voluminous entries of the dictionaries these two draw upon; numbering follows the above; only those items and nuances that go beyond MSA are given):

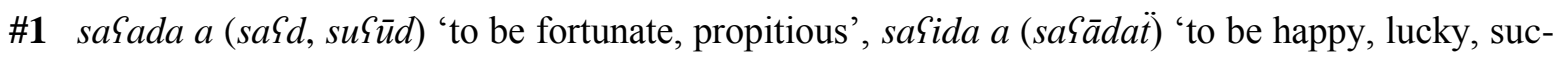
cessful', suৎdān 'prosperity, salvation, blessing', istaşada (X) 'to seek fortune; to find one's happiness ( $b i$ - in); to find one happy, fortunate; to deem propitious or auspicious'

\#2 [as in MSA]; sāaid 'armlet' (so called after the forearm on which it is worn); sāaidä̈ (pl. sawā ${ }^{2} d^{u}$ ) 'shaft of a pulley, piece of wood that holds the pulley'

\#3 saSdānä̈ 'nipple of the (female) breast, areola of the nipple, wart, callosity, knob; callosity of a camel's breast; knot of the thong of sandals, in the ropes of a scale'

\#4 [as in MSA]

\#5 suৎādà or suৎdä̈ 'Cyperus, sedge, galingaile (plant)', saৎdān 'neurada procumbens, plant much sought for camels', tasaৎ̧ada (V) 'to seek the plant saSdān for a pasture, seek for fodder'

\#6 saSd (pl. suSüd) 'name of several stars'; al-saSdān (dual) 'the two planets Venus and Mercury

5 >https://ar.wikipedia.org/wiki/قائمة_الانفعالات_العاطفية > (as of August 01, 2017).

6 Ibid.

7 The first serving as default, the second abbreviated "(S)" and given only if significantly different from Hava 1899. 
(S: Venus and Jupiter)'

\#7 sawā $S_{i d}$ (sg. sāaid) 'the channels in which water runs to a (small) river, affluents of a river/rivulet; the medullary cavities, ducts through which runs the marrow in a bone; ducts in the udder from which the milk comes to the orifice of the teat'; (nahr) saGid '(river, rivulet, canal of running water) that irrigates the land in the parts adjacent to it'

\#8 $\quad$ sâaidä̈'lion'

\#9 sāGidä̈ 'marrow'

\#10 saSdānä̈ 'pigeon'

Ad \#1 and \#2: The root is attested only in West Semitic. Outside Arabic, it does not display the aspect of 'good fortune, luck' but only that of 'help, support, assistance, aid'. ${ }^{8}$ Attestations within Semitic being rare, it is difficult to decide whether this aspect was secondary in Arabic, a semantic extension building on a primary Semitic *'help, support' ('good fortune, luck' interpreted as "assistance" from destiny or a divine power) or whether an original Semitic *'good fortune, luck' was lost in all other languages, except Arabic. The former possibility seems more likely, as many other values, both in Arabic and other Semitic languages, can be understood as derivations from 'help, support, assistance, aid'. 'In Arabic, one of the most common ones is certainly sâaid 'forearm' (*'the supporting one'). On the other hand, the Arabic value 'good fortune, luck', too, has quite a number of derivations, as we will soon see below.

Ad \#3: According to Lane, ${ }^{10}$ the 'nipple (or the areola) of a woman's breast' has its name after the '(head of) prickles' of the plant called safdān which is 'one of the best kinds of pastures of camels'; thus, \#3 seems to depend on \#5.

Ad \#4: The ape is called saSdān 'the lucky one' euphemistically, as Nöldeke explains in his often quoted "Wörter mit Gegensinn (Aḍd $\bar{a} d)$ ": "Des Affen Anblick bringt Unglück; daher heißt er euphemistisch sądān 'boni augurii' [sic!]."11

Ad \#5: Following Hess, Landberg/Zetterstéen's Glossaire datinois identifies the plant that is such a good pasture for camels as "Neurada procumbens". ${ }^{12}$ Connected to \#1 'luck' (*'to be lucky to find this plant')? Or to \#3 'prickle, knob' (*'plant with prickles')?

Ad \#6: The planets are so called because they are associated with good luck and prosperity (\#1).

Ad \#7: It is not clear whether this is a value in its own right or whether it is dependent on \#1 'luck' (water symbolizing s.th. positive) or \#2 'help, support, assistance' (the *channels "assisting" the main stream). Cf. also the expression saSada ' $l$-mā ? $u$ fì ' $l$-Pard 'the water came upon the land unsought, i.e., came flowing [naturally] upon the surface of the land, not requiring a machine to raise it for irrigation'.

Ad \#8: Not explained in Lane, nor do I have a plausible explanation myself.

Ad \#9: Dependent on \#7-result of a transfer of meaning from the channels of the marrow to the marrow itself.

Ad \#10: Perhaps not simply 'pigeon' but, as explained in Lane, 'name of a certain pigeon'; thus it is probably secondary, dependent on \#3 'nipple' (*'looking like...' or 'showing prickles'). Given the prominent role of the pigeon in Oriental mythology as a messenger of good fortune, one could however also think of a connection with the notion of \#1 'luck' ${ }^{13}$

\section{Trust-tiqä̈}

VWTQ

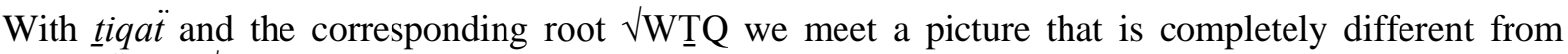
saৎādät and $\sqrt{ } \mathrm{SCD}$. The root is widely attested (though not in East Semitic) and shows practically no

8 Cf. BDB 1906: Biblical Hebrew sā̧ad 'to support, sustain, stay', Aramaic şad 'support, stay', Zincirli şd 'to strengthen, support', Chr.-Palestinian saSdūna 'aid'). - Showing ? instead of $\mathcal{G}$, Ugaritic s?d 'to serve s.o.' may be a borrowing from Canaanite, as Tropper 2008 observes.

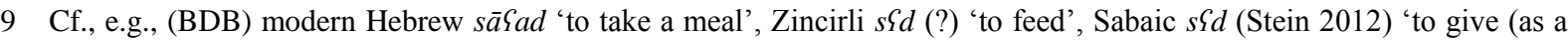
present)', (Müller 2010) 'to allow', all interpretable as specialisations of "support, assistance”.

10 s.v. sądān.

11 Nöldeke, NBSSW, 89, referring to "Wetzstein in ZDMG, 23:312 and Yahuda, in 'Orient. Stud.' (für Nöldeke) 408".

12 Landberg/Zetterstéen 1943: 1933, referring to Hess, Der Islam, 7 (1916): 104.

13 Cf. the Biblical pigeon signalling the end of the Great Flood and the association pigeons with 'peace' - another interesting example of travelling ideas and emotions. 
ambiguity. ${ }^{14}$ It seems safe to assume that the notion of 'trust' is the result of a metaphoric transfer of meaning from a primary sense of 'to bind, tie, fasten, make firm' which appears in Ugaritic ( $y \underline{t} q$ ' 'lier, attacher') ${ }^{15}$ and is also preserved in Modern South Arabian (Mehri wītaq $q$, Jibbāli étzq 'être fixé') ${ }^{16}$ and Arabic (watuqa 'to be firm, solid', watāa $q$, wit $\underline{a} q$ ' 'tie, bond, fetter, shackle, chain', watīiq 'firm, strong, solid'). ${ }^{17}$ The transfer itself, however, is also very old, as it can be found in many Semitic languages ${ }^{18}$ where the non-figurative meaning often does not even exist anymore, and the notion of 'trust' has generated a broad field of derived ideas. ${ }^{19}$

The rather uncomplicated etymology of tiqä̈ notwithstanding, we should however not pass to the next emotion without mentioning that tiqä is certainly not the only term to render English 'trust'. As 'joy' could be expressed by many other terms than sąādä̈, so could also 'trust' be translated as Pamānä̈ 'reliability, trustworthiness; loyalty, faithfulness, fidelity, fealty; integrity, honesty; confidence, trust, good faith; deposition in trust; trusteeship; confidentiality, secrecy', tuma?ninnä̈ / itmi?nān 'calm, repose, serenity, peace, peacefulness, tranquility; reassurance, peace of mind, composure, calmness, equanimity; trust, confidence', tawakkul 'trust, confidence; trust in God; passivity of living (of the early ascetics and mystics)', ...

\section{Fear-hawf}

$\sqrt{\mathbf{H W F}}$

Hawf 'fear' is equally unambiguous as tiqä̈, probably because it is a similarly basic word for a similarly basic emotion. In the whole entry on $\sqrt{\mathrm{HWF}}$ in $\mathrm{Wehr} / \mathrm{Cowan}$, there is not one single item that would not be derived from hawf or the corresponding verb hafa \#1 'to be frightened, scared; to be afraid ( $\min$ of), dread ( $\min$ s.o. or s.th.); to fear (s.th., s.o. or $\min$ s.o., s.th.; Galà for s.o., for s.th.; ?anna that)'. In Classical Arabic, the situation looks slightly different. In addition to \#1 'fear, fright, to fear, frighten; awe, concern, worry' - the only value surviving in MSA-, Badawi \& Abdel Haleem 2008 also list 'to know, suspect, become aware' (which however is still a direct offspring from 'fear'), 'unworthy act; fighting' (cf. Hava 1899: hawf 'slaughter, fighting', hawäf 'bustle, confused noise'), and 'to decrease, shorten'. A closer look into the attestations given for the latter values makes clear, however, that we are not dealing with genuine polysemy here either since all of them seem to be context-dependent variations of 'to fear'. The only item that we obviously have to distinguish from \#1 etymologically is \#2 hăafä 'leather-garment worn by collectors of honey, leather-bag for honey', mentioned in Hava 1899 as well as DRS 10 (2012). ${ }^{20}$

Although all my sources remain silent about the origin of \#2, ${ }^{21}$ it does not seem very likely that it is related to \#1. As for the latter, "our" 'fear', its-however scarce-attestation in three major branches of Semitic ${ }^{22}$ (with little probability of inner-Semitic borrowing) is probably satisfactory evidence to

14 Kogan 2015: 314 excludes a relation to Ugaritic $y q \check{s}$ 'fowler, bird-catcher', Hebrew $y q s ̌$ 'to catch a bird with a snare', etc., as well as to GəYəz waqaśa 'to reprimand, reproach' and related Ethio-Semitic forms. Tropper 2008, too, thinks that a connection between Arabic watiqa 'fest machen, befestigen' and Ugaritic $y \underline{t} q<* w \underline{t} q$ 'emporschnellen (Schlange)' and GəSəz wsq, wśq 'to bend (a bow), shoot (from a bow); to stretch, pull, straighten up' is little probable. Also quite unlikely is any outer-Semitic dimension (Albright had compared $18^{\text {th }}$ dyn. Egyptian isq 'zögern, verweilen; trans. zurückhalten' to Arabic watuqa 'to be firm', but Calice 1936 \#510 has already ruled out this with good arguments).

15 DRS 7 (1997) \#WTQQ-1. - Cf., however, Tropper 2008: 143, who thinks that Ugaritic $y \underline{t} q$ rather means 'emporschnellen' (to leap up, said of a snake) and with this sense is more likely to be akin to Gə؟əz لWSQ, WŚQ 'to bend (a bow), shoot (from a bow); stretch, pull, straighten up' than to Arabic watiqa.

16 DRS 7 (1997) \#WTQ-1.

17 Wehr/Cowan 1979. - Ehret 1995 \#981 thinks triradical Semitic $\sqrt{W T Q}$ is based on bi-consonantal * $w \underline{t}$ 'to twist' < Afroasiatic *-wits- or *-wic- 'to twist (tr.)'. In his opinion, other extensions from the same base can be found in Arabic wat ? (vn.) 'to sprain one's wrist', watal 'rope of bast', and waty (vn.) 'to be sprained, bruised, injured (hand)'.

18 Targum Aramaic wattīq 'fidèle, pieux, habile, excellent', Sabaic w $\underline{t} q$ 'confier' - DRS 7 (1997) \#WTQ-1.

19 (DRS 7 \#WTQ-1:) Maltese wettaq 'confirmer, renforcer, revigorer', wittieq: partie de la navette; Sabaic $h w t q$ 'garantir',

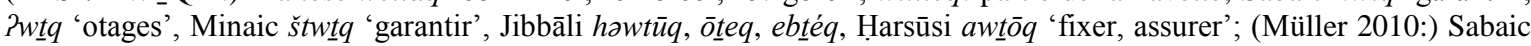
?wțq 'Bürge'; (Wehr/Cowan 1979:) Arabic watīqä̈ 'document, deed, writ, instrument, paper, record, voucher, certificate, receipt, policy; diplomatic note', mîta $\bar{a} q$ 'covenant, agreement, contract, treaty, pact, alliance; charter', tawtiqä̈ 'security, surety, guaranty', muwattiq 'notary public'.

20 To this one will also have to put hawf 'ornamented skin' - Hava 1899.

21 According to $D R S$, it is Eastern Arabic only.

22 Akkadian ḩāpu, Arabic ḩāfa 'avoir peur', Mehri ḩwīf, Soqoțri hayef 'craindre' - DRS 710 (2012) \#HWP-1. 
assume a common Semitic origin. Akkadian hāpu 'to fear, be afraid' is mentioned both by $D R S$ and Zammit but, strangely enough, not in $C A D$. The only item to be found there as close in meaning would be hip(i) libbi 'panic, anxiety', from hìpu (var. hību, hippu), '1 break, 2 gully, 3 cut-off piece', related to hep $\hat{u}$ 'broken, split', thus meaning * 'breaking of the heart', in the sense of 'loss or lack of courage'. But is this from $\sqrt{H W F}$ ? It seems that, as for now, etymology cannot get beyond this point.

\section{Surprise-mufäğa?ä̈}

In MSA, mufäğa?ä is certainly the most common word to express the notion of 'surprise'. However, given that surprise, according to Plutchik, is a basic emotion one might ask why such a basic emotion should be expressed by a form III verbal noun, i.e., a derived form rather than a "more basic" one. A search for mufäğa?ä in the premodern section of a huge textual database like arabiCorpus ${ }^{23}$ does indeed not yield more than 17 hits. The meagre result is probably due to two facts: a) 'surprise' is an abstract concept, while the majority of premodern texts are of a more concrete nature - an assumption that is supported by the fact that the hits predominantly stem from treatises or other theoreticalphilosophical texts; b) neither the noun mufäğa?ä̈ nor the corresponding verb fäğa?a are the usual terms to express the notion of 'surprise' in Classical Arabic. (Note that it does not even figure in The Thousand and One Nights, although the legendary collection of stories is full of highly surprising events!) No wonder then that Monteil would count mufäğa?ä among the neologisms that mark the difference between the classical and the modern language. ${ }^{24}$ It seems that in Classical Arabic expressions belonging to the "more basic" form I of the same root $\sqrt{ } \mathrm{FG}$ ? are more common - the verbal noun $f a \check{g}$ ?a $\ddot{t}$, at least, mostly used adverbially in the indeterminate accusative, fağ?ătan , meaning 'suddenly, coming as a surprise', gets 68 hits in the same corpus. Moreover, even though items belonging to $\sqrt{F G}$ ? thus are not unknown to the classical language, the notion of 'surprise' is most often rendered by words stemming from other roots, like $r \bar{a} S a$ ( $\sqrt{R W S}$ ) 'to startle, surprise' (but also 'to frighten, scare, alarm'), ${ }^{25}$ Galà $\left(h \overline{i n}^{i}\right)$ girrä̈ ( $\sqrt{\mathrm{GRR}}$ ) 'unexpectedly, unawares, inadvertently, surprisingly', bagata (I) or bāgata (III) ( $\sqrt{ } \mathrm{BG} T)$ 'to surprise; to come unexpectedly, descend in unawares', or the very widespread dahaša or (pass.) duhiša ( $\sqrt{ } \mathrm{DHS})$ 'to be astonished, amazed, surprised; to wonder, marvel; to be baffled, startled, puzzled, perplexed, taken aback' ${ }^{26}$

As for mufäğa?ä and the root $\sqrt{\mathrm{F} G}$ ? , it seems difficult to establish a somehow convincing etymology. There are obviously no direct cognates in Semitic. With one exception (see below), more recent etymological studies remain completely silent about the root, and among the older ones it is only BDB who thinks that Hebrew pāga (Aramaic $p^{2} g a \varsigma$, Semitic $\sqrt{ }$ PGS) 'to meet, encounter, reach', i.e., a form

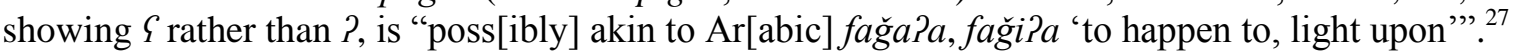

While this juxtaposition would suggest a primary meaning of * 'to meet unexpectedly, run into' we may also build further upon Gabal's finding that the bi-consonantal nucleus $F \breve{G}$ - from which both $F \breve{G}$ ? and $F \breve{G}\{$ possibly were formed as tri-consonantal extensions actually signifies a 'sudden, unexpected opening, ${ }^{28}$ (cf. also the "sudden" break-through of the first sunrays at 'dawn', fağr , or the wide 'opening, aperture, breach, gap, interstice', fağwä - to mention only two other triradical roots containing an

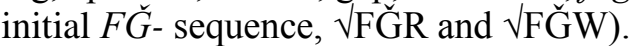

In a similar vein, one could also expand on Bohas' Le son et le sens where $\sqrt{F G ̆}$ ?, though not explicitly mentioned, would probably be counted among the derivatives of the "etymon" $\{\breve{\mathrm{g}}, \mathrm{f}\},{ }^{29}$ which also comprise items like ğahafa 'to peel off, scrape off; to sweep away', ğafala 'to start, jump with fright; to shy, be startled', fağąa 'to inflict suffering and grief (upon s.o.), afflict, distress / frapper, affecter, accabler qn (se dit d'un malheur qui fait perdre à qn qc qui lui est cher)', farağa 'to open, part

$23<$ http://arabicorpus.byu.edu>, as of Aug. 04, 2017.

24 Monteil 1960: 113.

25 Cf. also raw $a \ddot{t}$ 'fright, alarm, fear; awe; astonishment, surprise; perplexity; charm, beauty, magnificence, splendour' Wehr/Cowan 1979.

26 For the sake of convenience, all values are given as in Wehr/Cowan 1979, but their use in MSA is not different from that in the classical language.

27 BDB 1906: 803. The Semitic root given in the parentheses is the one reconstructed by Goshen-Gottstein 1970: 61.

28 Gabal 2012, iii: 1668 and 1672.

29 Unlike for Gabal, for Bohas the sequence of the radicals within the root is interconvertible. 
separate, cleave, split, ...', falağa 'to split, cleave', etc. ${ }^{30}$

Among all the studies I have consulted Bishtawi is the only one that explicitly mentions the root $\sqrt{ } \mathrm{FG}$ ?. Limitation of space does not allow us to go into detail here; therefore it may suffice to draw a table of all the roots that, according to the author, are akin to $\sqrt{F G}$ ? (highlighted in bold capital letters): ${ }^{31}$

\begin{tabular}{|c|c|c|c|c|c|c|c|c|}
\hline Nuclei & * ğf & *ğb & ${ }^{*} \mathrm{kf}$ & ${ }^{*} \mathbf{q f}$ & ${ }^{*} \mathbf{f g ̆ ~}$ & *bğ & ${ }^{*} \mathrm{fk}$ & ${ }^{*} f q$ \\
\hline gemin. & ğff & ğbb & kff & qff & f̆ğg & b̆ğğ & $\mathrm{fkk}$ & fqq \\
\hline redupl. & ğfğf & ğbğb & kfkf & qfqf & f̆̆f̆ğ & bğbğ & fkfk & fqfq \\
\hline$-w / y$ & ğfw & ğby & kfy & qfw & f̆gw & b̆g w & - & fqw \\
\hline$-?$ & ğf? & ğb? & $\mathrm{kf?}$ & qf? & FĞ? & - & - & fq? \\
\hline$-t$ & ğft & ğbt & $\mathrm{kft}$ & - & - & - & - & - \\
\hline$-\mathbf{g}$ & - & ğb̆g & - & - & - & - & - & - \\
\hline -ḥ & - & ğbḥ & kfḥ & qfh & - & bğḥ & - & fqh \\
\hline$-b$ & ğfh & ğbh & $\mathrm{kfh}$ & qfh & - & - & - & fqh \\
\hline$-d$ & - & - & - & qfd & - & b̆gd & - & fqd \\
\hline$-r$ & ğfr & ğbr & $\mathrm{kfr}$ & qfr & fğr & bğr & $\mathrm{fkr}$ & fqr \\
\hline$-z$ & ğfz & ğbz & - & qfz & f̆ğZ & - & - & - \\
\hline$-s$ & ğfs & ğbs & $\mathrm{kfs}$ & qfs & f̆ğs & b̆gs & - & $\mathrm{fqs}$ \\
\hline$-\mathbf{s}$ & ğfr̃ & ğbš & - & $\mathrm{qf \tilde {s }}$ & f̌ğš & - & - & - \\
\hline -s & - & - & - & qfṣ & - & - & - & fqș \\
\hline$-t$ & - & - & - & qft & - & - & - & - \\
\hline$-\varsigma$ & ğfৎ & ğbS & - & qfS & f̆ğ & - & $\mathrm{fk} \varsigma$ & $\mathrm{fq} \mathrm{F}$ \\
\hline-1 & ğfl & ğbl & $\mathrm{kfl}$ & qfl & fğl & bğl & $\mathrm{fkl}$ & $\mathrm{fql}$ \\
\hline$-m$ & - & - & - & - & fğm & bğm & - & fqm \\
\hline$-n$ & ğfn & ğbn & $\mathrm{kfn}$ & qfn & fğn & - & $\mathrm{fkn}$ & - \\
\hline$-h$ & - & ğbh & $\mathrm{kfh}$ & - & - & - & $\mathrm{fkh}$ & fqh \\
\hline
\end{tabular}

\section{Sadness-huzn}

$\sqrt{H} \mathbf{H Z N}$

The Arabic root $\sqrt{\mathrm{HZN}}$ to which the usual word for 'sadness' belongs shows two values, both in the classical and the modern language: \#1 'to be(come) sad', and \#2 'rough, rugged, hard ground'. The second one appears only in a few items, like hazn (pl. huzūn) in the meaning just mentioned, ${ }^{32}$ huznat 'montagne escarpée', ${ }^{33}$ huzūnä̈ 'ruggedness of the soil', or Pahzana (IV) 'to walk upon a hard ground' ${ }^{34}$ Putting the second value in the first place, Badawi \& Abdel Haleem, in their arrangement of values in the classical language, implicitly suggest a semantic development as follows (my reading in square brackets, S.G.): '[\#2] rocks, boulders, rocky hard-going terrain; [ > ] to cause hardship, distress; [ > ] to afflict; [> \#1] to become sad, to grieve, sadness; [>?] responsibility' ${ }^{35}$ Although such a development cannot be excluded with certainty, the evidence from cognates in Semitic is not strong enough

30 Bohas, Le son et le sens, Annexe au livre Le son et le sens, <http://www.ifporient.org/node/1200>.

31 Cf. Bishtawi 2013: 38.

32 Wehr/Cowan 1979.

33 DRS 9 (2010) \#HZWN-2.

34 Hava 1899, s.v.

35 Badawi \& Abdel Haleem 2008, s.v. 
to claim that \#1 'sadness, grief' is not dependent on \#2 'rough, rugged, hard ground'-apart from Arabic, 'sadness' is not attested beyond Modern South Arabian and Ethio-Semitic, where influence from Arabic is widespread. ${ }^{36}$ However, if 'sadness' originally really is *'hardship/distress caused by a rocky terrain', then Arabic would be the only language to have preserved the primary value, while all others would have lost it. On the other hand, a development in the opposite direction (\#1 > \#2) is difficult to imagine, and we would have to explain a case of genuine homonymy.

In conclusion, it seems that the modern Arabic word for 'sadness', huzn, may not reflect the original Semitic word for this emotion. To find this, one may instead have to look into the etymologies of

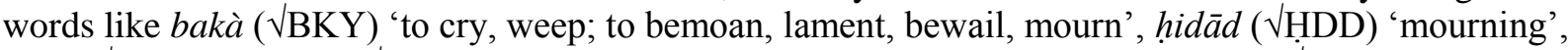
ratà $(\sqrt{ } R \underline{T Y})$ and rata $\bar{a}(\sqrt{ } R \underline{T} W)$ 'to bewail, lament, bemoan; to eulogize', or naSà ( $\sqrt{ } N S Y)$ 'to lament, wail; to deplore' — a task that is beyond the scope of the present contribution.

\section{Disgust-išmi?zāz}

ل $(\check{\mathbf{S} M 2 Z)}, \check{\mathbf{S} M Z}$

Like in other cases we have treated so far, the term given in the above-mentioned article as modern equivalent of one of Plutchik's basic emotions, in this case $i s ̌ m i ? z \bar{a} z$ for 'disgust', is only one out of a variety of other terms that the translator could have chosen. Although $i s ̌ m i ? z \bar{a} z$ is already Qur'anic, ${ }^{37}$ there are a number of terms that would seem "more original" than the word that actually means "to contract, shrink (with aversion)', like, for instance, Sayf ( $\sqrt{ } \mathrm{YYF}$ ) 'disgust, loathing, horror, aversion', qaraf ( $\sqrt{\mathrm{QRF}}$ ) 'loathing, disgust, detestation', taqazzuz ( $\sqrt{\mathrm{QZZ}}$ ) 'loathing, disgust, detestation, abhorrence, aversion', karh, kurh $(\sqrt{ } \mathrm{KRH})$ 'hatred, hate; aversion, antipathy, dislike, distaste; detestation, abhorrence, disgust, repugnance, loathing', or nafrä̈ ( $\sqrt{N F R})$ 'aversion, distaste, dislike, antipathy ${ }^{38}$ And like with other modern terms for emotions, etymological research soon reaches its limits also in the case of išmi?zzazz, even though it is, like the others, considered "basic" emotion. Dictionaries and other works of reference usually treat the 4-radical $\sqrt{\mathrm{S}} \mathrm{MPZ}$ as a root extension from $\sqrt{\mathrm{S}} \mathrm{MZ}$ (as also $\sqrt{T}$ MPN is grouped under $\sqrt{T} M N$, etc.). This latter root hasn't a modern representative any longer, but Classical Arabic still knows šamaza u (̌̌amz) 'to feel disgust, to loathe s.th. ${ }^{39}$ However, this root does not seem to have any direct cognates in Semitic either. ${ }^{40}$ Relatives of it may only be found if we accept, if to a certain degree, the theory that many triradical roots are extensions of earlier biradical ones or that they at least contain a biradical semantic nucleus. ${ }^{41}$ The most prominent exponent of the first variant is probably Christopher Ehret, in whose two major elaborations on the theory we find indeed two "pre-proto-Semitic" roots * $t m$ - from which the author thinks several 3-consonantal roots with an initial $\breve{S} M$ - were formed in Arabic. In the 1989 publication, the author reconstructs such a * $t m$ - meaning 'up, high'. ${ }^{42}$ This, however, does not seem to have an extension in $-z^{43}$ and its meaning can hardly be connected to the notion of 'disgust'. In the second, we meat a $* \mathrm{~lm}$ - meaning 'to depart' (from an assumed Afroasiatic *tăam- 'to leave'). ${ }^{44}$ From this, Ehret derived not only šamğara 'to flee

36 DRS 9 (2010) \#HZN-1 gives the following cognates of Arabic hazina 'to be(come) sad': Mehri hzzūn, Jibbāli ahzin, Harsūsi hayzen, hezōn, Soqoțri házon, GəSəz hazana, hazna, hazana 'être triste, être en deuil', Tigre hazna, Tigriñña h̆azänä, hazänä, Argobba hazzänä, Amharic azzänä, Gurage azänä 'être triste', Harari huzni 'tristesse'; ? Sabaic hhżn 'abîmer, endommager'. - Calice 1936 \#737 mentions also neo-Egyptian h̆ğn 'to be(come) angry; to resist', adding however that the latter should probably rather be interpreted as a $h$ - form from ğnğn $\sim d n d n$ 'to be angry'.

37 Q 39:45 wa-Pid do not believe in the Hereafter shrink with aversion whenever God is mentioned on His own' (my italics, S.G.).

38 All values as in Wehr/Cowan 1979.

39 Hava 1899. - Cf. also tašammaza (V) 'to contract, to get altered (face)', ibid.

40 The only reference work that has an entry on $\sqrt{\mathrm{S}} \mathrm{M}($ (?)Z, Zammit 2008, shows only blanks for all the Semitic languages it covers.

41 For a concise presentation of the pros and cons of this so-called 'biradicalism' theory, cf. Zaborski 2011. For a comprehensive discussion, cf. Voigt 1988.

42 Ehret 1989 \#24.

43 The items Ehret himself (ibid.) derives from this *lm- 'up, high' are šamma (لك̌SMM) 'to be proud', šamam (dto.) 'height,

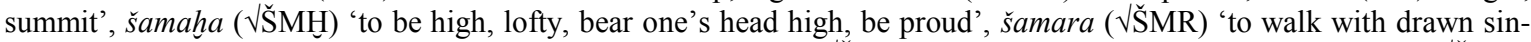

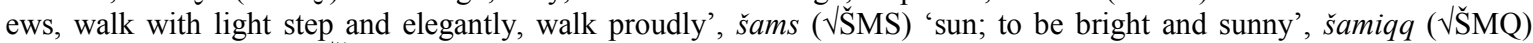

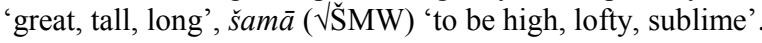

44 Ehret 1995 \#878. 
in terror' and šamara 'to walk with a light step' but also šamaza 'to run away'. ${ }^{45}$ If we follow this reading we have to interpret "our" išma?azza 'to detest, be disgusted' as being based on a root $\sqrt{\text { ŠMZ }}$ with the original meaning 'to shrink back' <*'to run away' < pre-proto-Semitic *tm- 'to depart' < Afroasiatic *tăam- 'to leave'. - A scholar who follows the second variant (a semantic kernel attached to the first two consonants of a triconsonantal root) is the late Egyptian professor of Arabic, Muhammad Hasan Hasan Gabal. ${ }^{46}$ In his Muৎ̆̆am ištiqāqu mu?așșal he identifies the basic meaning of the nucleus $\check{S} M$ - as 'withdrawal/retreat of s.th. extended/spread upwards, becoming finer' (insihā $b$ al-šay? al-muttasif (al-muntašir) Pilà ?ąlà mustadiqqan) or 'collection/aggregation of what is/was spread out, retreating/withdrawing upwards' (ğamৎ mā huwa muntašir munsahiban Pilà ?ąlà). ${ }^{47}$ In Gabal's ğam 'collecting, assembling what was spread, etc.', one may rediscover the 'shrinking' (*'contraction') contained in the modern meaning of išmirzzazz, while he also feels that the connection to a movement upwards overlaps with Ehret's * $m$ - 'up, high'.

Summing up, we may say that it seems that with the help of Ehret and Gabal we may have come slightly closer to the possible origins of Arabic išmi?zāa, without however being able to confirm any of our approximations through clear evidence from outside Arabic. The ultimate etymology will therefore have to remain obscure until the day we discover further material for comparison.

\section{Anger- $\dot{\text { gadab }}$}

$\sqrt{\mathbf{G} D \mathbf{B} B}$

At first sight it looks as if the material on which to build etymological hypotheses is a little broader in the case of gadab 'anger'. After all, has not Růžička left a whole article entitled 'Zur Etymologie von $\dot{g} d b{ }^{\prime \prime}{ }^{48}$ The fact, however, that the space designed for Semitic cognates in Zammit's study on the etymology of the Qur'anic lexicon remains completely void ${ }^{49}$ may raise doubts. And indeed, on a closer look, the case turns out to be far from simple and easy. Růžička starts his discussion by

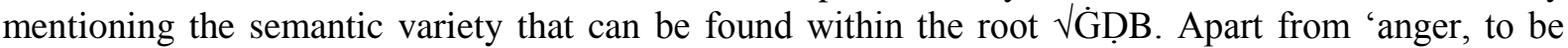
angry', he says, it also comprises words like ${ }^{50} \dot{g} i / u d \bar{a} b$ 'mote(s) in the eye', ${ }^{51} \dot{g} a d b a \ddot{t}$ 'skin of a mountain goat advanced in age', or $\dot{g} a d b a ̀$ ' (herd of) a hundred camels'. These, however, are only a few out of a much larger variety (as was also the case with other items, see above). From the dictionaries of Classical Arabic the following picture emerges (preliminary grouping according to main semantic values by myself, S.G.):

\#1a $\dot{g} a d b$ 'intense in redness'; hence also the elative al-?aggdab ('the reddest one') signifying \#1b 'the part between the penis and the thigh';

\#2a gadiba a (gadab) 'to be angry'; hence also \#2b 'to defend, protect s.o.' (<*to rise in anger against an aggressor);

either from \#1a or \#2a may be the use of gadb for the \#1/2c 'lion' and for the \#1/2d 'bull';

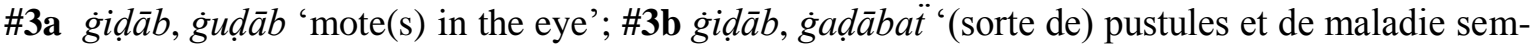
blables à la petite vérole [small-pox]', gudiba 'to be afflicted with the desease called gidāa (said of camels)', gadbä̈ 'protuberance (of flesh) above or beneath the eyes (or the upper eyelid) in the form of a flatulent tumour, patch of the small-pox, pock-mark';

\#4a gadbä̈'skin of a mountain goat advanced in age, of a fish, of the head, of the parts between the horns of a bull'; hence also \#4b 'shield (made of the hides of camels), garment (made of the hides of camels) worn for fighting';

\#5 gadbà '(herd of) a hundred camels';

\#6 $\dot{g} a d b(a \ddot{t})$ 'hard stone, rock'.

45 Values found in Steingass 1884.

46 For a presentation cum discussion of his approach, cf. Guth 2017.

47 Gabal 2012, ii: 1198, 1204, respectively.

48 Růžička 1914.

49 Zammit 2002.

50 Meanings given in German by Růžička are replaced with the corresponding English ones as found in Lane's dictionary.

51 Růžička has also 'Strohhalm' (straw) here. I am dropping this value here since I was unable to verify it in any of the dictionaries I consulted. 
It seems clear that also \#1, \#2 and \#3 somehow belong together, but from the Arabic evidence alone it is difficult to decide which of the three should be the primary one: is 'redness' dependent on 'anger' or vice versa, or are perhaps the little pustules in the eye(lid)s of a camel, caused by a certain disease, the eponym of 'intense redness' or 'anger'?

Unfortunately, a look beyond Arabic into Semitic does not help very much to make a decision since there are indeed no direct or obvious cognates. The situation becomes even more complex because the two initial radicals, $\dot{g}$ and $d$, though part of the proto-Semitic phonemic inventory, have merged in other Semitic languages with original $\zeta$ and $s$, respectively. Assuming a reverse development inside Arabic, Růžička connects gadiba 'to be(come) angry' with Sadda 'to bite', suggesting that the biradical nucleus * $\dot{g} d$ - is secondary, developed from * $\mathcal{\varphi} d$ - 'to cut, separate, cut with the teeth, bite'. He thinks that the verb Sadaba 'to cut off' ${ }^{52}$ reflects both the primary form and the primary meaning; that $\dot{g} a d i b a$, after a $* \xi_{-}>\dot{g}$ - shift, has preserved this original sense of 'cutting' in a few instances ${ }^{53}-$ the author interprets even \#6 'hard stone, rock' as *'the sharp, cutting one'-; elsewhere, however, he continues, gadiba has taken on a figurative meaning, along the line *'to cut > bite > be savage, vicious $>$ be scathing, aggressive $>$ be infuriated, angry', a shift that, according to Růžička, must have taken place at an early time since it can be observed already in what the author believes to be Hebrew and Aramaic cognates of gadiba, namely, e.g., Hebrew $\zeta \bar{a} s \underline{s} \underline{b}$ 'to hurt, pain, grieve' ${ }^{54}$ More recent research, however, holds that Arabic Sadda 'to bite' has "no clear parallel elsewhere in Semitic". 55 And Leslau does not compare the items that Rưžička connected to Arabic $\sqrt{\text { ĠDBB }}$ to the latter but to $\sqrt{\varsigma S ̦ B}$, or (with metathesis) perhaps also $\sqrt{S} S_{\varsigma B}{ }^{56}$ — so that $\sqrt{\text { ĠDB }}$ now is left without cognates.

It seems that the question whether gadab 'anger' is at the semantic origin of 'intense redness' and/or the small-pox-like 'tumours/pustules' in a camel's eye, or whether one of the latter values represents the primary notion from which 'anger' and others are derived by a transfer of meaning, or whether all go back to an earlier 'biting' which perhaps is from a still earlier 'cutting' - this question will have to remain unsolved until the possible appearance of fresh material that would introduce new aspects. In the meantime the suggestion made - implicitly — by Badawi \& Abdel Haleem may also be worth some consideration: mentioning the 'protruding rock' (\#6 gadb, -ä̈) at the beginning of their enumeration of the values attached to $\sqrt{\mathrm{G} D B}$ in Classical Arabic they seem to insinuate that the idea of a *'protrusion' might be at the basis of all others. Such an assumption could explain the values of group \#3, i.e., the 'swelling' in a camel's eye and the small-pox-like tumours/pustules caused by the eruption of the $\dot{g} u d \bar{a} b$, as well as the eruption of \#2 'anger, ${ }^{57}$ and perhaps even the 'intense redness' could be explained (as the redness of the affected eyes, of the pustules, or the face of the infuriated one).

But still... Neither (\#4) the 'skin of a mountain goat [...]' and the 'shield/garment made of the hides of camels' nor (\#5) the '(herd of) a hundred camels' have found a place in any of the above theories, so that there is even less to say about their possible, or impossible, relation with gadab 'anger'.

Furthermore, if gadab should not be a primary idea but a derived notion, the result of a transfer of meaning, wouldn't it then be reasonable to look for other "more original", "more basic" lexical items to express Plutchikian anger? Apart from gadab, aspects of 'anger' can be rendered by hanaq 'fury, rage, ire, wrath, anger, exasperation, resentment, rancor', suh(u)t or sahat 'discontent, annoyance, displeasure, indignation, anger, irritation; wrath, bitterness, grudge, resentment', gayz 'wrath, anger, ire, exasperation, fury, rage', ...

52 Cf. also the only ؟ḌB item that is preserved in MSA, 乌aḍ bsharp, caustic, acid (tongue)' - Wehr/Cowan 1979, s.v.

53 E.g., he translates a sample sentence, given in the dictionaries-ġadiba 'l-haylu Salà 'l-luğmi-not as 'the horse became infuriated of, or revolted against, the bridles' but as 'the horse bit on the bridles'.

54 To this, BDB connects also GəYəz Sașaba 'to be hard, difficult', while the mentioning of Arabic gadiba is preceded by a question mark.

55 Kogan 2015: 29 (fn.): GəSəz Yașș̣a 'to deprive, cause harm, rob, take away by force' has more straightforward cognates in Arabic.

56 Thus, we get this group of cognates: Hebrew $\Upsilon \bar{a} s \underline{a} \underline{b}$ 'to pain', Aramaic $\varsigma^{a} \underline{s} a \underline{b}$ 'to be grieved', Arabic $\{a \underline{a} a b a$ 'to bind,

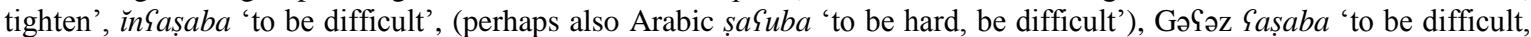
hard, harsh, troublesome, grievous, serious' - Leslau 2006, s.r. ؟ȘB.

57 Badawi \& Abdel Haleem 2008, s.r. ĠDB. 
Like mufäğa?ä for 'surprise', the word that translates Plutchik's 'anticipation' in the above-mentioned Wikipedia article, tawaqquৎ, looks very modern and "unoriginal". But it actually isn't, as a search in the premodern texts of arabiCorpus makes clear: while mufäğa?ä̈ only got 17 hits, tawaqquS yields $90 .^{58}$ But still, this result does not mean that tawaqqu was established as a concept in its own right already in premodern times. Rather, it seems that it was used only as a "gerund" ('expecting', not 'expectation, anticipation') until the late $19^{\text {th }} /$ early $20^{\text {th }}$ century. Regular dictionaries of Classical Arabic like Freytag 1838 or de Biberstein-Kazimirski 1860 only register the verb (V) tawaqqaSa 'to expect, wait for s.th. to happen'. ${ }^{59}$ Today, however, the verbal noun has been lexicalized, and according to Buckwalter \& Parkinson's Frequency Dictionary ${ }^{60}$ it even forms part of the basic vocabulary, scoring on place 3040 of the authors' frequency list of contemporary written Arabic (the verb is even on position 804 !).

Morphologically, tawaqqu is a verbal noun of tawaqqa $a$, a form $\mathrm{V}$ verb derived from the corresponding form I, waqa $a$ (impf. yaqaৎu, vn. wuqū $\uparrow$ ) 'to fall; [...] to come to pass, take place, occur; to happen (li- to s.o.), befall; [...]'. As an extension in self-referential/reflexive $t$ - of the causative form II, waqqaSa 'to let fall, bring down, make happen', the form $\mathrm{V}$ verb tawaqqaSa literally means *'to let fall, bring down, make happen for oneself', so that 'expectation, anticipation' basically means *'imagination of s.th. that will/can happen/be the case, will befall (the speaker)' ${ }^{61}$

While Huehnergard thinks that $\sqrt{W Q 9}$ in the sense of 'to fall, happen' is an exclusively "Arabic root", ${ }^{62}$ other scholars ${ }^{63}$ not only see it related to Modern South Arabian and Ethio-Semitic items, ${ }^{64}$ but also go beyond the Southern Semitic sphere, paralleling it with $\sqrt{ } \mathrm{YQ}^{65}{ }^{65}$ or another, homonymous $\sqrt{W Q}$, the most prominent exponents of which are Hebrew yāqaS 'to be dislocated, alienated' and GəSəz waqৎa 'to strike, flay, skin, strip off, cut, bruise, crush'. ${ }^{66}$ The authors of DRS are a bit more reluctant: a "?" marks their separation between \#WQS-1 'to fall' and the possibly related \#WQS-2, which in their opinion not only comprises, as just mentioned, Hebrew yāqa؟ 'être disloqué, cassé (membre)' and GəSəz waq $a$, waq?a 'frapper, écorcher, couper, écraser', but also Arabic waqaৎa 'frapper, battre (avec un marteau), aiguiser, amincir; marquer (un cheval au fer rouge)', ${ }^{67}$ mìqaSat 'marteau, maillet, battoir à linge'; Harsūsi mēqe $e h$ 'mortier'; Tigre wäq $a_{a}$ 'battre, battre le grain', Tigriñña wäqəSa 'battre, pleuvoir', Amharic wäqqa 'battre, abattre', Argobba wäqqa, and Gurage wäq(q)a 'battre'. - While \#WQS-1 and \#WQS-2 may be related, a similar kinship seems difficult to imagine for a third value, figuring as \#WQS-3 in DRS: Arabic waqi endoloris, les sabots usés par la marche sur un sol rocailleux' [Hava 1899: I \& II 'to abrade (the hoofs:

$58<$ http://arabicorpus.byu.edu>, as of Aug. 14, 2017.

59 No entries (neither for tawaqqu as a lexical item in its own right nor under the correspronding verb, tawaqqa9a, nor as renderings of English 'anticipation' or 'expectation') in Zenker 1866, Wahrmund 1870, Catafago 1873, Spiro 1895 and 1897, Hava 1899. In Bustānī 1869 and Steingass 1884, the noun tawaqquS is not lexicalized as a separate item, but the verb tawaqqaSa does appear, with the meaning 'to expect, look for, prepare one's self for, hope; to meet with one's wish accidentally' (Steingass). It is only Wahrmund 1887 who has tawaqquS 'Erwartung, Hoffnung' alongside with tawaqqa\}a (vb., V) 'etwas (bes. Unangenehmes) erwarten, sich darauf gefaßt machen, hoffen [...]; zufällig (auf das Gewünschte) stoßen, es finden, erlangen (Galà)'.

60 Buckwalter \& Parkinson 2011.

61 Interestingly, English case is also from 'to fall', cf. OED (as of Aug. 14, 2017): "case: early 13c., 'what befalls one; state of affairs,' from Old French cas 'an event, happening, situation, quarrel, trial,' from Latin casus 'a chance, occasion, opportunity; accident, mishap,' literally 'a falling,' from cas-, past participle stem of cadere 'to fall, sink, settle down, decline, perish' [...], from P[roto]I[ndo]E[european] root *kad- 'to lay out, fall or make fall, yield, break up' [...]. The notion being 'that which falls' as 'that which happens' (compare befall)."

62 Huehnergard 2011, s.r. $w q$ S.

63 Such as Zammit 2002 and Rajki 2002.

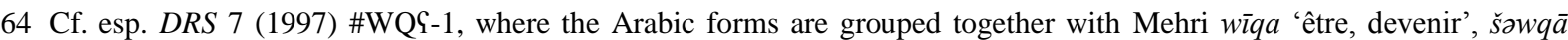

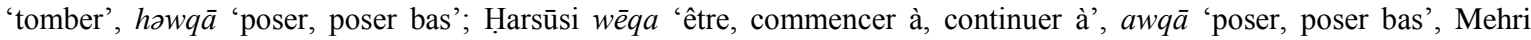
Harșūṣu waqōna 'à peu près, peut-être'; Jibbāli éqaS (l-) 'trouver, tomber juste, deviner', Pabqa؟ 'mettre', sabqaS 'tomber'; Soqoțri aqa€ 'deviner'; Tigriñña wäq $i$, Amharic mäwqe 'accès brusque de fièvre'.

65 Rajki 2002 even reconstructs a proto-Semitic $* \sqrt{ }$ YQS.

66 GəSəz values as in Leslau 2006 s.v.

67 Cf. Hava 1899: Arabic waqaSa 'to slander, dishonour (fi s.o.)', waqqaSa (II) 'to sharpen (a sword) with a hone' 
stony ground)']; waqaS 'nudité des pieds; rochers, pierres' [Hava 1899: waqiSa (impf. yawqaSu, vn. waqas) 'to go barefoot; to have the feet chafed by a hard ground', waqis 'barefooted; having the feet chafed by a hard ground', waqas 'rocks'].

Given that inner-Semitic etymology still is rather obscure, it is probably too early to attempt, as Orel \& Stolbova did, a reconstruction not only of Semitic *wVkaS- 'to fall', but also (based on additional evidence from some West and Central Chadic languages) Afroasiatic *wakas- 'to fall' ${ }^{68}$ But their suggestions may not be too far from the truth either...for the semantic complex of 'to fall', at least - the values appearing sub \#3 (to abrade the hoofs, go barefoot, have the feet chafed by hard ground, hard ground/rocks) still remain etymologically "homeless".

To conclude this section with a note on the margin: Would it ever have occurred to your mind that Arabic tawaqqu 'anticipation' could be akin to the European name of the brightest star in the constellation of Lyra, Vega? But this is actually the case. Vega goes back to Arabic (al-nașr al-) wāqif '(the) falling/attacking (eagle, or vulture)', the Arabic name for this star which, like tawaqquS, is formed from waqaSa' to fall, come down on'. 69

\section{Conclusion}

On the preceding pages we have tried to establish the etymology of eight terms that an Arabic Wikipedia article gave us as modern Arabic equivalents of the English words for what Robert Plutchik identified as eight "basic emotions". After this attempt, some observations and remarks are in place:

$>$ In contrast to the more "tangible" basic vocabulary (physical world, kinship, animals, body, food and drink, housing, etc.), there is very little previous research on which our investigation could build, emotional terminology does not seem to have received due scholarly attention yet-a lacuna that is all the more deplorable as there is no reason why this terminology should be considered less "basic" than that for the more "tangible" phenomena. ${ }^{70}$

$>$ Sometimes, however, emotional terminology is indeed the result of figurative use of a more "concrete" basis, as could be observed in the case of saSādä̈ 'joy, happiness' (perhaps from 'to be assisted, get support'), tiqä̈ 'trust' (probably ultimately from 'tie, bond, chain'), ǐsmi $2 z \bar{a} z$ 'disgust' (probably from 'to shrink, contract, shudder away'), or gadab 'anger' (perhaps based on 'intense redness', 'mote in the eye', or 'small tumour, patch of small-pox').

$>$ For many of the terms we have looked into no straightforward cognates outside Arabic are attested. In these cases, any etymological statement, if possible at all, has to remain vague and speculative, at best approximative (mufăğa?ä / $\sqrt{ } \mathrm{FĞ}$ : perhaps somehow related to a hypothetical nucleus

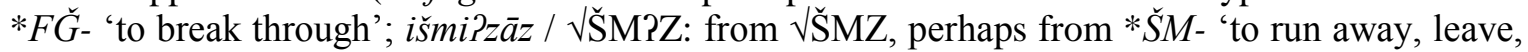
depart').

$>$ But even if cognates (or what looks like them) can be found in Semitic, they are often attested in parts of the Semitic area only. Cases like that of hawf 'fear' which has cognates in at least two other subgroups (Akkadian, Modern South Arabian), or $\sqrt{S S D}$ (Arabic + Hebrew, Aramaic, Sabaic), or $\sqrt{W Q 9}$ (Arabic + Modern South Arabian and Ethio-Semitic, perhaps also Hebrew) are rather exceptional. In other cases, attestations stem from only one or two (often closely related) branches so that etymological digging does not reach deeper/earlier layers.

$>$ However even if an item is widely attested outside Arabic, the look over the rim into Semitic sometimes does not help much, it may even be confusing — as in the case of gadab 'anger', which is probably neither related to Hebrew $\{\bar{a} s \underline{a} \underline{b}$ 'to hurt, pain, grieve' nor Arabic $S a d a b a$ 'to cut off' and the bi-consonantal $\sqrt{ } \mathrm{G}$ : (GDD) 'to bite'. In these cases only the discovery of fresh and qualitatively different evidence could possibly shed some light.

68 HSED 526 \#2518.

69 Huehnergard 2011. - First attestation in English 1638 - OED, as of Aug. 14, 2017

70 As a praiseworthy exception from the rule we may note the fact that "Emotions and Values" are treated, as a semantic field in their own right, in Haspelmath \& Tadmor's World Loanword Database (WOLD). Among the first items in this field we find also most of "our" Plutchik'ian emotions: \#16-15 'surprised or astonished' (cf. 'surprise'/mufäğa?ä); \#1618 'good luck' and \#16-23 'happy' (cf. 'joy, happiness'/saSādä̈); \#16-32 'grief' (cf. 'sadness'/huzn); \#16-33 'anxiety' and \#16-53 'fear' (cf. 'fear'/hawf); \#16-42 'anger' (cf. 'anger'/gadab); \#16-63 'to hope' (cf. 'anticipation'/tawaqqu९) <http://wold.clld.org/semanticfield/16>, as of August 16, 2017. 
$>$ In quite a number of cases, the Arabic terms with which the author of the above-mentioned Wikipedia article renders Plutchik's terms seem to be only one out of a large variety of possible translations. This testifies, on the one hand, to the banal fact that complex phenomena like emotions rarely have 1:1 correspondences in other languages, particularly so when these languages belong to different cultures. On the other hand, many of these terms (as, e.g., sacāalä, mufäğa?ät, išmi?zāz, tawaqqu\}) seem to be rather late "inventions", they cannot be traced (at least not as emotional concepts in their own right) in premodern texts, or are only very rare there. They seem to be examples not so much of "traveling" emotions as the results of a standardisation, globalisation, and "modernisation" of emotions. Older terminology that actually did exist and often was more common obviously was felt not to be adequate any longer. As the Arabic language still does not have an historical dictionary in which the interested user would find information about semantic change, innovation, borrowing, calquing, etc. over the centuries, we can only guess that the processes that were responsible for the replacement of older terminology with new one were connected to the "synchronisation" of the Arab world with "the" world, sometime during the so-called "long nineteenth century", or the Nahdah (often rendered as "Arab Renaissance" but probably better addressed as "Arab cultural modernity"). Research on linguistic change, and conceptual change in particular, during the Nahdah cannot be said to be non-existent; on the whole, however, previous research in this field has been either formalistic (identifying patterns of word formation, etc.) or mainly informed by an interest in political and social history. The result was again the neglection of many aspects of the Nahdah, among them its "emotional history".

$>$ Apart from traveling in time and across languages, regions and cultures, concepts often also move from one semantic field to others. The figurative use of "tangible, concrete" vocabulary to circumscribe certain emotions that we saw above was already one example of this type of transfer of meaning. But we have also, in the present article, come across examples of a transfer of emotional terminology itself: a pair of planets was called 'the lucky ones' because they were associated with good fortune; a pigeon was addressed as saSdānä̈, either because it seemed to be, like the planets, a bringer of good news, or due to its showing prickles. Sometimes, however, the transfer is less straightforward: a monkey is only euphemistically called saSdān 'the lucky one'; actually, it is associated with bad luck, misfortune. And sometimes it is also less a (metaphorical) transfer than an (metonymical) extension: gadiba, for instance, not only means 'to be infuriated' but also 'to defend (i.e., to rise in anger against an aggressor)'.

$>$ What the present contribution was not able to do, given limitation in space, was to follow Arabic emotional terminology on its journey into other languages that in fact borrowed much of this terminology in the course of Islamisation. E.g., we meet Arabic huzn again in Persian hozn, Turkish hüzün or Swahili huzuni; Arabic saYādä̈ reappears as Persian sa'ādat and Turkish saadet; Arabic gadab is the origin of Azeri qezeb, Swahili ghadhabu, Persian gażab, Turkish gazap, Uzbek $g^{\prime} a z a b$, etc. In some cases, it seems, the borrowings from Arabic into other languages may give us some indication about Arabic emotional terminology before the above-mentioned "synchronisation/globalisation/modernisation": In Turkish, for example, the word for 'disgust' is nefret which, via Persian nefrat, is from Arabic nifrä̈, a word that could well have served as equivalent of 'disgust' but in this sense obviously was replaced with išmi?zāz after being borrowed into Persian...

\section{Bibliography}

Badawi, El-Said, and Muhammad Abdel Haleem. 2008. Arabic-English Dictionary of Qur'anic Usage. Leiden: Brill.

$\mathrm{BDB}=$ Francis Brown, with the cooperation of S.R. Driver \& Charles A. Briggs: The Brown-Driver-Briggs Hebrew and English Lexicon. With an Appendix Containing the Biblical Aramaic. $13^{\text {th }}$ printing, Peabody, Mass.: Hendrickson Publ., 2010. (Reprinted from the 1906 edition originally published bz Houghton, Mifflin and Co., Boston.)

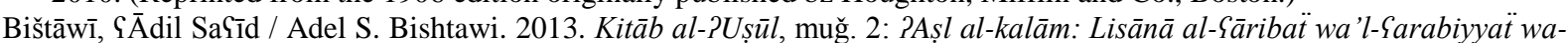
?ușūlu-humā al-ǧinnīniyyä̈ fĭ Sașr al-hağar / Book of Origins, Part II: Origin of "Semitic" Languages. Revision 14b - 25 September 2013. 〈http://bishtawiadel.com/wp-content/uploads/2017/08/Origin_of_Semitic_Languages_red.pdf>, as of August 17, 2017.

Buckwalter, Tim, and Dilworth Parkinson. 2011. A Frequency Dictionary of Arabic: Core Vocabulary for Learners. London $\&$ New York: Routledge.

Bustān̄i, Buțrus al-. 1869. Qațr al-muhīṭ. Beirut.

$\mathrm{CAD}=$ The Assyrian Dictionary of the Oriental Institute of the University of Chicago. [coll.]. 21 vols. Chicago \& Glückstadt: 
1956-2011.

Calice, Franz. 1936. Grundlagen der ägyptisch-semitischen Wortvergleichung: Eine kritische Diskussion des bisherigen Vergleichsmaterials / edited by Heinrich Balcz. Wien: Selbstverlag des Orientalischen Institutes der Universität. (Beihefte zur Wiener Zeitschrift für die Kundes des Morgenlandes; 1 . Heft).

Catafago, Joseph. 1873. An English and Arabic Dictionary, in Two Parts: Arabic and English, and English and Arabic. $2^{\text {nd }}$ edition, carefully corrected, improved, and enlarged. London: Bernard Quaritch.

DRS = Cohen, David, François Bron et Antoine Lonnet. 1994- . Dictionnaire des racines sémitiques ou attestées dans les langues sémitiques, comprenant un fichier comparatif de Jean Cantineau. Leuven: Peeters.

Ehret, Christopher. 1989. "The Origin of Third Consonants in Semitic roots: An Internal Reconstruction (Applied to Arabic)". Journal of Afroasiatic Languages, 2/2: 107-202.

- 1995. Reconstructing Proto-Afroasiatic (Proto-Afrasian): Vowels, tone, consonants, and vocabulary. Berkeley and Los Angeles: University of California Press.

Ğabal, Muhammad Ḥasan Hasan. 2012. al-Mu乌̆gam al-ištiqāqī al-mu?așsal li-Palfāz al-qur?ān al-karīm: mu?așșal bi-bayān al-\{alāqāt bayn Palfāz al-qur?ān al-karīm bi-Pașwāti-hā wa-bayn maȲānī-hā. 4 vols. Cairo: Maktabat al-?Ādāb.

Goshen-Gottstein, M. H. 1970. A Syriac-English Glossary, with Etymological Notes: Based on Brockelmann's Syriac Chrestomathy. Wiesbaden: Otto Harrassowitz.

Guth, Stephan. 2017. "Biradicalist Mimophonic Triradicalism: Sounds, Root Nuclei and Root Complements in M. Ḥ. Ḥ. Gabal's 'Etymological' Dictionary of Arabic (2012)”. JAIS 17 (2017): forthcoming.

Haspelmath, Martin and Uri Tadmor (eds.). 2009. World Loanword Database (WOLD). Leipzig: Max Planck Institute for Evolutionary Anthropology. 〈http://wold.clld.org>, accessed on August 16, 2017.

Hava, J. G. 1899. al-Farāîid al-durriyya fì 'l-lugiatayn al-Sarabiyya wa'l-Pinkilīziyya = Arabic-English Dictionary for the Use of Students. Beirut: Catholic Press.

$H S E D=$ Orel, Vladimir E. and Olga V. Stolbova. 1995. Hamito-Semitic Etymological Dictionary: Materials for a Reconstruction. Leiden [etc.]: Brill (HdO I. Abt., 18. Bd.).

Kogan, Leonid. 2015. Genealogical Classification of Semitic: The Lexical Isoglosses. Boston/Berlin: Walter de Gruyter.

[de] Landberg, [Comte] Carlo: Glossaire datinois, 3 vols. Leiden: Brill, 1920, 1923, 1942 (publ. by K. V. Zetterstéen).

Lane, Edward William. 1863-94. An Arabic-English Lexicon. 8 vols. London: Williams and Norgate. $<$ http://www.laneslexicon.co.uk/>

Leslau, Wolf. 2006. Comparative Dictionary of Ge'ez (Classical Ethiopic): Ge'ez-English / English-Ge 'ez, with an Index of the Semitic roots. Wiesbaden: Harrassowitz.

Müller, Walter W. 2010. Sabäische Inschriften, nach Ären datiert: Bibliographie, Texte und Glossar. Wiesbaden: Harrassowitz.

Nöldeke. 1910. "Wörter mit Gegensinn (Aḍdād)". In Nöldeke 1982, II: 67-108.

Nöldeke, Theodor. 1982. Beiträge und Neue Beiträge zur Semitischen Sprachwissenschaft: Achtzehn Aufsätze und Studien, teilw. in 2., verb. u. vermehrter Aufl. Amsterdam: APA-Philo Pr., 1982. (Repr. in 1 vol. of the Strassburg 1904-1910 two-vol. edition).

$O E D=$ Harper, Douglas. 2001-2017. Online Etymology Dictionary. <http://www.etymonline.com/>.

Osman, Nabil. 2015. Deutsch-Arabisches Wörterbuch / unter Mitwirkung von Abbas Amin. Wiesbaden: Harrassowitz.

Rajki, András. 2005. Arabic Dictionary [with etymologies]. Version 2.2, <https://archive.org/details/ArabicEtymologicalDictionary>.

Růžička, Rudolf. 1914. "Zur Etymologie von $\dot{g}-d-d-b$ ". Zeitschrift für Assyriologie, 28: 280-86.

Schregle, Götz. 1982. Deutsch-Arabisches Wörterbuch. Wiesbaden: Franz Steiner Verlag.

Spiro, Socrates. 1895. An Arabic-English Vocabulary of the Colloquial Arabic of Egypt: Containing the Vernacular Idioms and Expressions, Slang Phrases, etc., etc., Used by the Native Egyptians. Cairo: al-Mokattam Printing Office / London: Bernard Quaritch.

Spiro, Socrates. 1897. An English- Arabic Vocabulary of the Modern and Colloquial Arabic of Egypt. Cairo: al-Mokattam Printing Office / London: Bernard Quaritch.

Stein, Peter. 2012. Lehrbuch der sabäischen Sprache. 2. Teil: Chrestomathie. Wiesbaden: Harrassowitz.

Steingass, F. [1884]. The Student's Arabic-English Dictionary: Companion Volume to the Author's English-Arabic Dictionary. London: Crosby Lockwood \& son.

Voigt, Rainer M. 1988. Die infirmen Verbaltypen des Arabischen und das Biradikalismus-Problem. Stuttgart: Franz-Steiner Verlag Wiesbaden. (= Akademie der Wissenschaften und der Literatur Mainz. Veröffentlichungen der Orientalischen Kommission; vol. 39).

Wahrmund, Adolf. 1870. Handwörterbuch der arabischen und deutschen Sprache. Band II: Deutsch-neuarabischer Theil. Giessen: J. Ricker'sche Buchhandlung.

Wahrmund, Adolf. 1887. Qāmūs Sarabī-nimsāwī / Handwörterbuch der neu-arabischen und deutschen Sprache. $2^{\text {nd }}$ edition. Giessen: J. Ricker'sche Buchhandlung.

Wehr, Hans, and J. Milton Cowan. 1979. A Dictionary of Modern Written Arabic. $4^{\text {th }}$ ed. Wiesbaden: Otto Harrassowitz. (Reprint Ithaca NY: Spoken Language Services, 1994.)

WOLD: see Haspelmath and Tadmor (eds.) 2009.

Zaborski, Andrzej. 2011 [= first online publication]. "Biradicalism". In: Encyclopedia of Arabic Language and Linguistics, Managing Editors Online Edition: Lutz Edzard, Rudolf de Jong. Consulted online on 12 February 2017 <http://dx.doi.org/10.1163/1570-6699_eall_EALL_COM_0046>.

Zammit, Martin R. 2002. A Comparative Lexical Study of Qur?ānic Arabic. Leiden [etc.]: Brill. (HdO, section I; 61).

Zenker, Julius Theodor. 1866-67. Türkisch-Arabisch-Persisches Handwörterbuch. 2 vols. Leipzig: Wilhelm Engelmann. 